\title{
Arthrogryposis: an update on clinical aspects, etiology, and treatment strategies
}

\author{
Bartłomiej Kowalczyk, Jarosław Feluś
}

Department of Orthopedics, University Children's Hospital, Krakow, Poland

Submitted: 8 December 2013

Accepted: 4 March 2014

Arch Med Sci 2016; 12, 1: 10-24

DOI: 10.5114 /aoms.2016.57578

Copyright @ 2016 Termedia \& Banach

\begin{abstract}
Arthrogryposes - multiple joint contractures - are a clinically and etiologically heterogeneous class of diseases, where accurate diagnosis, recognition of the underlying pathology and classification are of key importance for the prognosis as well as for selection of appropriate management. This treatment remains challenging and optimally in arthrogrypotic patients should be carried out by a team of specialists familiar with all aspects of arthrogryposis pathology and treatment modalities: rehabilitation, orthotics and surgery. In this comprehensive review article, based on literature and clinical experience, the authors present an update on current knowledge on etiology, classifications and treatment options for skeletal deformations possible in arthrogryposis.
\end{abstract}

Key words: arthrogryposis, etiology, surgical treatment, rehabilitation, orthotics.

\section{Introduction}

Arthrogryposis (arthrogryposis multiplex congenita - AMC) is not a separate disease entity, but is rather a descriptive diagnosis used to denote more than 300 individual diseases with varying etiologies. Their common feature is the presence of congenital, usually non-progressive joint contractures involving at least two different body areas. This class of diseases includes the so-called classic arthrogryposis - amyoplasia, with its unique clinical features such as symmetrical, severe contractures, usually involving both the upper and lower limbs [1].

Most contractures in arthrogryposis require treatment; this potentially involves multiple surgical corrections of the knees and hips, correction of spinal deformities, elbow and wrist contractures, foot deformities, and of dislocations commonly accompanying the contractures; of these, the hip and knee are the most commonly affected joints [2-4]. The treatment of a child, and subsequently an adult, with arthrogryposis is a challenge - not only due to the nature of the disease and the resulting surgical technical difficulties, but also due to the required logistics of the complex multi-disciplinary treatment; this involves, among others, pediatricians, physiotherapists, geneticists, orthopedic surgeons, and orthotic specialists - all of whom need thorough knowledge and experience in the treatment of arthrogryposis patients [5-9].

As the population of patients with arthrogryposis - due to their expected survival matching that of the general population - grows to be

\author{
Corresponding author: \\ Bartłomiej Kowalczyk MD, PhD \\ Department of Orthopedics \\ University Children's Hospital \\ 265 Wielicka St \\ 30-668 Krakow, Poland \\ Phone: +48602664730 \\ E-mail: \\ kowalczyk012@gmail.com
}


a relatively numerous group, a number of treating specialists will see AMC patients - whether newborn, pediatric or adult - who will require at least counseling and potentially treatment. The objective of this review is to summarize contemporary concepts covering the topic of arthrogryposis, especially its etiology, diagnosis and treatment, for all professionals who are likely to see arthrogryposis patients, notably orthopedic surgeons, rehabilitation physicians, pediatricians, physiotherapists and nursing specialists.

\section{Definitions and incidence}

Arthrogryposis derives its name from Greek language ("arthron" - joint, "gryposis" - curvature); the name describes multiple configurations of congenital limb contractures, usually non-progressive and often gradually improving with appropriate management [1]. Historically, arthrogryposis was for the first time described as "congenital myodystrophy" in 1841 by Otto, and subsequently termed "multiple congenital contractures" by Schantz in 1897, and "arthrogryposis" by Rosenkranz [10-12]. The name "arthrogryposis multiplex congenita" used to date was coined by Stern in 1923 in a report on multiple symmetrical joint contractures in 3 patients [13]. Scheldon in 1932 described clinical features of congenital multiple contractures in a child and used for the first time the name "amyoplasia congenita" [14].

"Congenital contracture" denotes a limitation of the passive and active range of motion in a given joint or joints with coexistent structural and/ or functional abnormalities of the surrounding soft tissues - the joint capsule and periarticular ligaments. It is estimated that congenital joint contractures with varying degree of severity and involving at least one joint affect $1 / 100$ to $1 / 200$ live births; these may range from e.g. idiopathic talipes equinovarus, contractures of digits (camptodactyly, clinodactyly) or hip joint in developmental hip dysplasia to multiple joint contracture syndromes such as amyoplasia or Pena-Shokeir syndrome - a lethal form of multiple joint contractures [1, 15, 16]. Multiple contractures incidence ranges from $1 / 3,000$ to $1 / 5,000$ live births [17-19]. The term arthrogryposis is used to denote contractures involving at least two joints in two different body regions [20, 21]. According to Bamshad et al. the group also includes multiple contractures in the course of the so-called classic arthrogryposis (amyoplasia), distal arthrogryposis (DA), or syndromic arthrogryposis, where the contractures occur on the background of known genetic disorders [21].

Hall describes among multiple congenital joint contractures three subgroups of disorders, i.e. contractures mainly involving limbs (i.e. amyo- plasia, distal arthrogryposis type I and IX, Poland syndrome, camptodactyly), limb contractures with coexistent abnormalities of other systems (i.e. campomelic dysplasia, diastrophic dysplasia, Larsen's dysplasia, Kniest dysplasia, metaphyseal dysplasia, metatropic dysplasia, spondyloepiphyseal dysplasia, Freeman-Sheldon syndrome, Möbius syndrome, multiple pterygium syndrome, popliteal pterygium syndrome, nail-patella syndrome, Sturge-Weber syndrome, Marfan syndrome, osteogenesis imperfecta type II, neurofibromatosis) and limb contractures with central nervous system abnormalities (i.e. lethal multiple pterygium syndrome, lethal X-linked arthrogryposis, pterygium syndrome with facial clefting, cerebro-oculo-facial syndrome, fetal alcohol syndrome, Marden-Walker syndrome, Pena-Shokeir syndrome, Zellweger syndrome, myelomeningocele, myotonic dystrophy, spinal muscular atrophy, Turner syndrome, trisomies: 4p, 8,9,9q,10q, 13,15,18,21) [1]. In the differential diagnostics and classification of congenital contractures, the central nervous system function is the factor of paramount importance: pathological central nervous system symptoms indicate that the contractures have originated from reduced fetal movements on the background of primary central or peripheral nervous system pathology, or of the neuromuscular junction. Normal neurological examination usually indicates that contractures have originated in the fetal life in the form of classic AMC, DA, or other diseases [20, 21].

\section{Etiology}

The pathological mechanism of congenital joint contractures usually involves the absence of active fetal movements (akinesia), normally appearing in the eighth week of fetal life - fetal akinesia lasting over 3 weeks may be sufficient to result in absence of normal stretching of muscles and tendons acting on the affected joints, and cause reduced compliance of the joint capsule and periarticular ligaments, consequently leading to fibrosis and contractures of the affected joints determined by the passive position of the limb (Figure 1) [22]. The earlier the restriction of active fetal motion occurs, the greater the arthrogryposis severity; it is also considered that fibrosis of periarticular structures - both the ligaments and the articular capsule - may be responsible for the tendency of the affected joints to return to their original fetal position despite the used treatment, i.e. to recurrence of deformity $[1,23,24]$. This is confirmed by experimental studies including chicken fetuses; their results indicate that the absence of active motion in embryonic joints caused by e.g. administration of curare, or infection with Coxsackie or Newcastle viruses, results in joint stiffness resembling arthrogryposis $[25,26]$. The effects of 

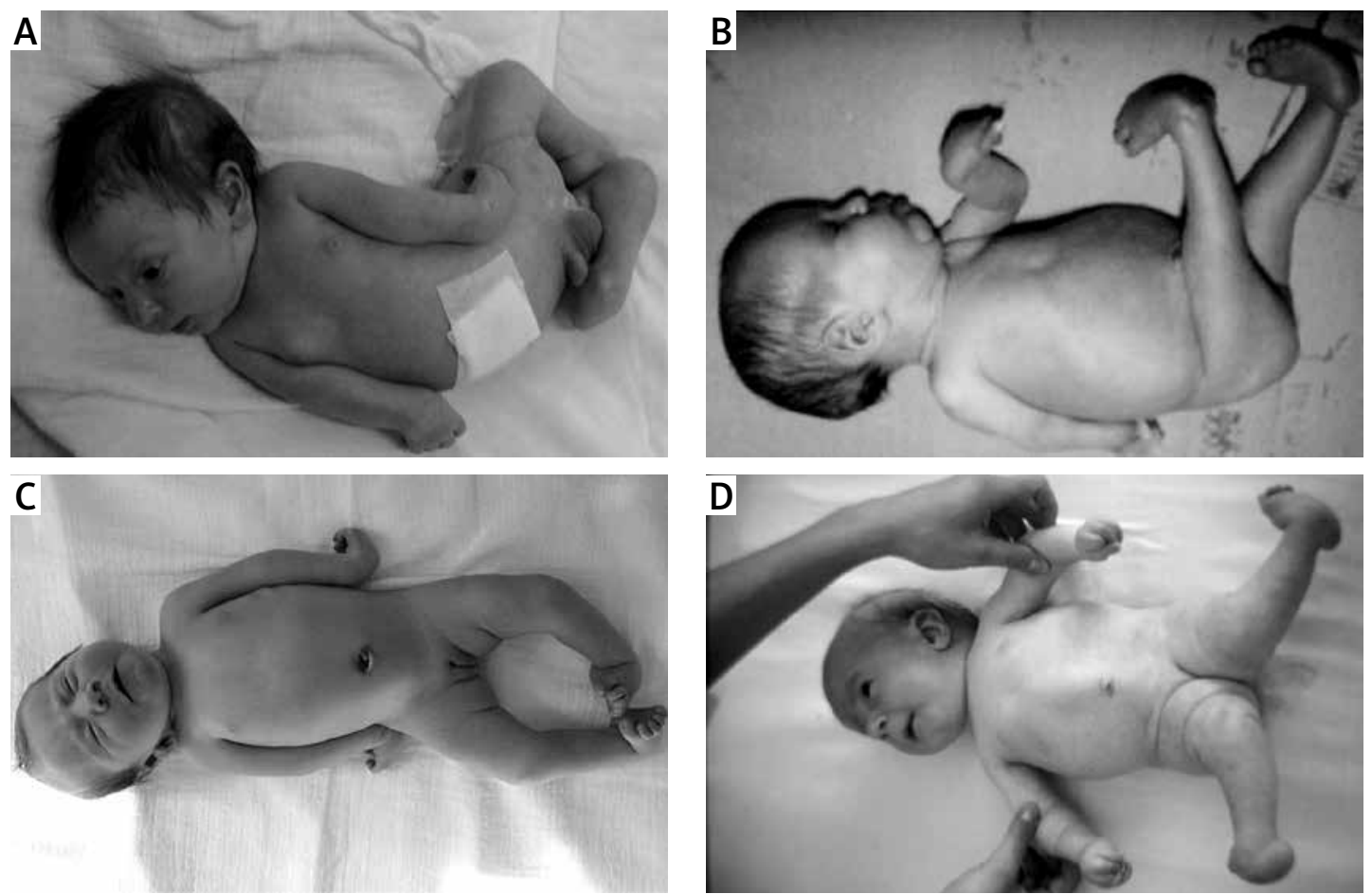

Figure 1. Clinical examples of multiple congenital contractures - arthrogryposis - in neonates

curare on rat embryos include multiple joint contractures, pulmonary hypoplasia, short umbilical cord, hypoplasia of the jaw, and polyhydramnios. These abnormalities have been termed the fetal akinesia syndrome, and a similar syndrome in humans is known as the Pena-Shokeir syndrome [23, 27]. The direct etiological factor causing akinesia in humans remains unknown, but a number of abnormalities can be discerned that can result in disruption of active movement and consequently fetal akinesia. These abnormalities may concern the fetus and include functional and/or structural pathologies, leading to hypomobility, such as:

- neurogenic factors (motor center diseases; disorders of the peripheral nerves or neuromuscular junction),

- myogenic factors (muscular dystrophies, mitochondrial diseases),

- diseases of the adjacent tissues and/or articular tissues (diastrophic dysplasia).

Alternatively, the abnormalities may concern the fetal environment:

- maternal diseases (myasthenia gravis, SM, diabetes),

- mechanical factors (anatomic abnormalities of the uterus; multiple pregnancy; oligohydramnios, amniotic bands),

- vascular and nutritional disorders.

\section{Neurogenic factors}

These are the most common cause of delayed and/or reduced fetal motor capabilities in ar- throgryposis patients $(70-80 \%)[1,16]$ and may include central nervous system disorders such as epilepsy, neuronal migration abnormalities, pyramidal disorders, and olivo-ponto-cerebellar disorders [28-31]. Diseases of the alpha motor neurons of the anterior spinal horns are a frequent cause of arthrogryposis, e.g. in X-linked spinal muscular atrophy or in Werdnig-Hoffmann disease [29, 30, 32, 33]. Banker in autopsy and microscope studies carried out on fetuses with congenital joint contractures described a number of pathologies in the alpha motor neurons of the anterior horns: ranging from complete absence of these cells, through their decreased number and abnormal development, to degenerative changes accompanied by corresponding degenerative changes in the spinal nerves. Skeletal muscles in neurogenic types of arthrogryposis are present, but their mass is significantly reduced; in the myogenic types the number and size of muscle fibers are decreased as they are replaced by fibrous and fatty tissues. A neurogenic origin of joint contractures was observed in $93 \%$ of the studied subjects, whereas a myogenic cause was observed in $7 \%$ [34, 35]. Peripheral neuropathies resulting in the development of joint contractures can also be caused by abnormal myelination or abnormal Schwann cell growth [36, 37].

Abnormal neural tube development, e.g. in meningomyelocele or in sacral agenesia, may result in secondary limitation of active fetal movements and congenital multiple joint contractures; their severity is dependent on the level of injury 
(malformation) of the neural tube [1]. Abnormalities of the fetal cholinergic receptor resulting from mutation of the CHRNG gene (MIM100730) are known to result in abnormal development of the neuromuscular junction and consequently in development of clinical features of arthrogryposis, e.g. in Escobar syndrome (multiple pterygium syndrome) [38, 39].

\section{Myogenic factors}

Primary myogenic multiple joint contractures (myogenic type arthrogryposis) are rare and may be structural or functional [34]. Myogenic amyoplasia can be caused by a defect of myogenesis-regulating genes, resulting in normal development of the connective tissue muscle matrix, developing from lateral mesoderm with simultaneous abnormal development of myocytes, originating from mesodermal somites; these are replaced by adipocytes [40]. Congenital muscular dystrophies, congenital myopathies (such as the autosomal dominant "central core disease", nemaline myopathy, intranuclear rod myopathy) are a genetically and clinically heterogeneous group of diseases, characterized by abnormal structure and function of myocytes, with clinical features of arthrogryposis. These diseases are caused by mutations of genes encoding skeletal muscle proteins, ryanodine receptors, or mutations of the gene encoding nuclear lamins A and C (laminopathies) [40-49].

Clinical features of arthrogryposis can also be observed in mutations of genes responsible for the troponin and actinin complex synthesis (troponin I, $\alpha$-actinin 3) or mitochondrial cytopathy [41-43].

\section{Disorders of periarticular structures}

An example of connective tissue abnormality resulting in joint contractures is a group of diseases called osteochondrodysplasias; clinical symptoms of arthrogryposis are observed in many of these: diastrophic dysplasia or metatropic dysplasia, Kniest syndrome, campomelic dysplasia, osteogenesis imperfecta, Jansen's metaphyseal dysplasia, Saul-Wilson syndrome, spondyloepiphyseal dysplasia, and others [1].

Diastrophic dysplasia is characterized by dwarfism, short limbs, multiple joint contractures, talipes equinovarus, and progressive kyphoscoliosis. The primary defect is the deficiency of sulfur enzyme in the connective tissue, mediated by a gene located in chromosome $5 q$ [50]. Tendons, despite normal structure, may have abnormal insertions and thus cause limited active fetal motion and consequently symptomatic arthrogryposis. This mechanism has also been observed in certain forms of distal arthrogryposis [17]. Collagen disorders resulting in replacement of muscle tissue by connective tissue and thickening of joint capsules have been observed e.g. in Larsen's syndrome, multiple pterygium syndrome, congenital arachnodactyly, and Beals syndrome [16, 24, 51, 52].

Another example of arthrogryposis in connective tissue diseases is restrictive dermopathy a usually lethal disease where a fibroblast abnormality results in loss of skin elasticity; the hard skin prevents normal fetal movements and causes joint contractures [53].

\section{Maternal diseases}

Congenital contractures may develop in children born to mothers with myasthenia gravis; in this disease, maternal antibodies against fetal acetylcholine receptors migrate through the placenta and damage the receptors, affecting the fetal muscle function and producing symptomatic arthrogryposis [54-56]. Elevated risk of arthrogryposis has been reported in mothers with multiple sclerosis (MS), diabetes, and myotonic dystrophy $[57,58]$. Fetal contractures can also occur in maternal diseases such as toxoplasmosis, rubella, varicella, Coxsackie viruses, and enteroviruses; toxins and drugs (alcohol, d-tubocurarine, methocarbamol, misoprostol, phenytoin, and cocaine); pyrexia or overheating (hot baths, hot spa), and serious abdominal trauma [1, 59-61].

\section{Intrauterine environment abnormalities}

These include any disorders resulting in mechanical limitation of the free active movements of fetal limbs. The causes include multiple pregnancy, oligohydramnios, uterine abnormalities (bicornuate uterus, uterine septum), solid tumors, and uterine fibrosis [62]. Fetal blood supply is another potential cause of reduced fetal active movements. Reduced blood supply to the developing neural and muscular structures may cause their dysfunction, akinesia, and symptomatic arthrogryposis after birth. Such cases may be observed in placental abruption, induced pregnancy termination, and in the "steal syndrome" in monozygotic twin pregnancy $[62,63]$.

\section{Genetics of arthrogryposis}

Arthrogryposis is a group of clinical symptoms that can be observed in many different genetic syndromes; these may result from sporadic single-gene mutations (e.g. autosomal dominant, autosomal recessive and $\mathrm{X}$-linked recessive inheritance patterns), chromosomal disorders (e.g. trisomy 18) such as deletion, translocation, or duplication, and mitochondrial disorders. Arthrogryposis in chromosomal aberrations often coexists with psychomotor retardation [1]. Some patients are mosaics: chromosomal aberrations can be de- 
tected in fibroblasts and are absent in blood cells $[1,64,65]$. A phenotypically identical presentation of arthrogryposis can sometimes be caused by mutations of different genes [66].

The following inheritance forms of arthrogryposis are known:

- Autosomal dominant, e.g. in distal arthrogryposis type I, with $50 \%$ inheritance risk;

- Autosomal recessive, e.g. in multiple pterygium syndrome (Escobar syndrome), with 25\% inheritance risk;

- X-linked recessive, where all daughters of a male carrier are carriers. Fifty percent of male children of these daughters can express arthrogryposis phenotype, whereas $50 \%$ of their female children will be carriers;

- Sporadic, with very low inheritance risk;

- Mitochondrial inheritance.

The development of molecular diagnostics has resulted in new possibilities of identification and mapping of genes responsible for arthrogryposis symptoms, i.e. chromosome $5 q$ - diastrophic dysplasia; chromosome 9q - distal arthrogryposis, nail-patella syndrome; chromosome $11 q$ - Kniest dysplasia, spondyloepiphyseal dysplasia; chromosome $15 q$ - Marfan syndrome [1].

\section{Clinical features}

\section{Amyoplasia, classic arthrogryposis}

As the name denotes ("a" - absence, "myo" muscle, "plasia" - development; non-development of muscles) this is a sporadic multiple contractures


Figure 2. A clinical example of arthrogrypotic contractures involving upper limbs alone syndrome, usually with symmetrical involvement of multiple joints in lower and/or upper limbs, presenting with a characteristic position of limbs in the neonate (Figure 1). The central nervous system function is normal; the muscle tissue is of ten replaced with fatty and fibrous tissues. This type of congenital contractures is most commonly seen in orthopedic clinical practice: it has an incidence of $1 / 10,000$ live births, i.e. it constitutes approximately $30 \%$ of all congenital contractures [1, 67-69]. Patients with amyoplasia have normal or above-normal intelligence, and their expected 20-year survival is $94 \%$; it is considered that they can survive until middle and advanced age without dysfunction of other organs caused by the primary disease. However, without appropriate treatment, their potential for independent ambulation and activities of daily living is reduced [68]. Appropriate comprehensive rehabilitation and surgical treatment results in regaining ambulatory function at the age of 5 years in $85 \%$ of patients [2]. However, aside from the severity of contractures and the used treatment, this function is affected by the power of the pelvic girdle and the quadriceps muscles as well as upper limb function [70]. The quality of life is primarily determined by upper limb function and the ability to perform personal care activities [6]. Sells et al. demonstrated that $75 \%$ of patients are able to feed themselves independently but only approximately $10 \%$ are able to independently dress, $35 \%$ to wash, and $25 \%$ to take a bath [2].

Classic arthrogryposis is characterized by symmetric involvement of all limbs in $60-92 \%$ of patients. Lower limb involvement alone is observed in $7-24 \%$ of patients, whereas upper limb involvement alone is observed in $1-13 \%$ of patients (Figure 2) $[2,16,71]$.

The clinical picture observed in most patients with the classic four-limb involvement is as follows:

- The shoulder - adducted and internally rotated. Deltoid muscle function is deficient.

- The elbow - most patients present with extension contracture of the elbows with deficient brachialis and biceps brachii function, resulting in absent or significantly deficient elbow flexion. Flexion contracture of the elbow is less commonly observed. The elbow joint is cylindrical in appearance and devoid of any skin creases (Figure 1).

- The wrist - most patients present with characteristic palmar flexion contracture with ulnar deviation and pronation of the hand. Patients with myogenic arthrogryposis may present with extension contracture of the wrist.

- The hand - finger contractures may vary in classic arthrogryposis, but the most common feature is increasing distally flexion contractures 
of interphalangeal joints. Metacarpophalangeal joints may present with relative extension contractures. The thumb is usually adducted. Finger contractures are usually stiff and most patients have significant deficiency of active finger movements; however, children with AMC often have unexpected abilities to perform daily functions - even with rudimentary active finger motion. In syndromic arthrogryposis "clenched fist" with "thumb in palm" deformities may be observed (Figure 3).

- The hip - contractures are common; these are mostly flexion, abduction, and external rotation contractures of varying degrees of severity. Unilateral or bilateral hip dislocation is observed in approximately $1 / 3$ of patients.

- The knee - the most common deformity is flexion contracture of varying severity; an extension contracture is less commonly observed and may be accompanied by knee dislocation (Figures 1, 4). Flexion contracture is usually associated with weak quadriceps and a "dimple" over the patella (Figure 5).

- The ankle joint and foot - deformities of these body regions are observed in nearly all AMC patients, with severe talipes equinovarus being the most common; less frequently vertical talus might be observed. All these deformities are characterized by usually extreme severity, difficulties in treatment and high tendency to relapse (Figure 1) $[67,68]$.

- The spine - abnormal curvatures are observed in approximately $28 \%$ to $67 \%$ of patients; most commonly these are simple long thoracolumbar curves without concomitant vertebral malformations; however, the curves often rapidly progress (Figure 6) [7, 72, 73].
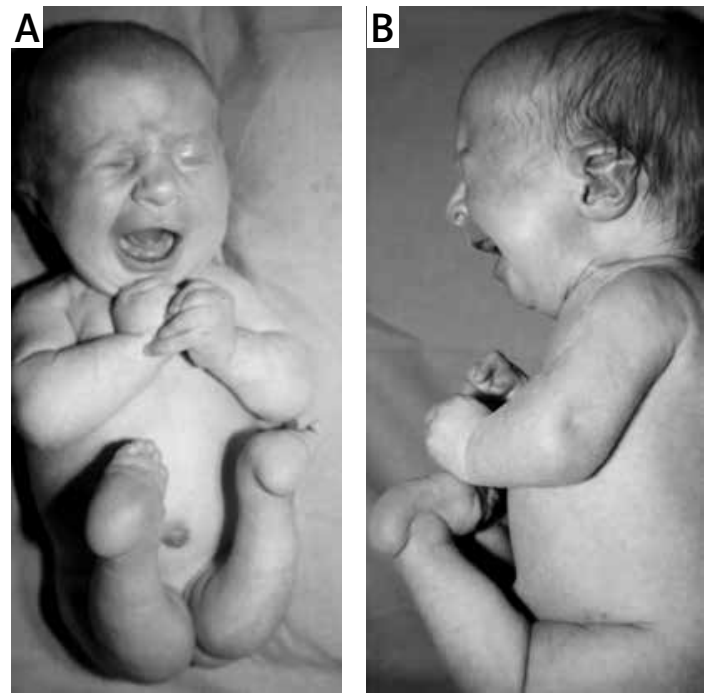

Figure 4 A, B. A clinical example of arthrogryposis with flexion contractures of the elbows, "clenched fist" deformities of the hands, knee dislocations, and bilateral congenital vertical talus
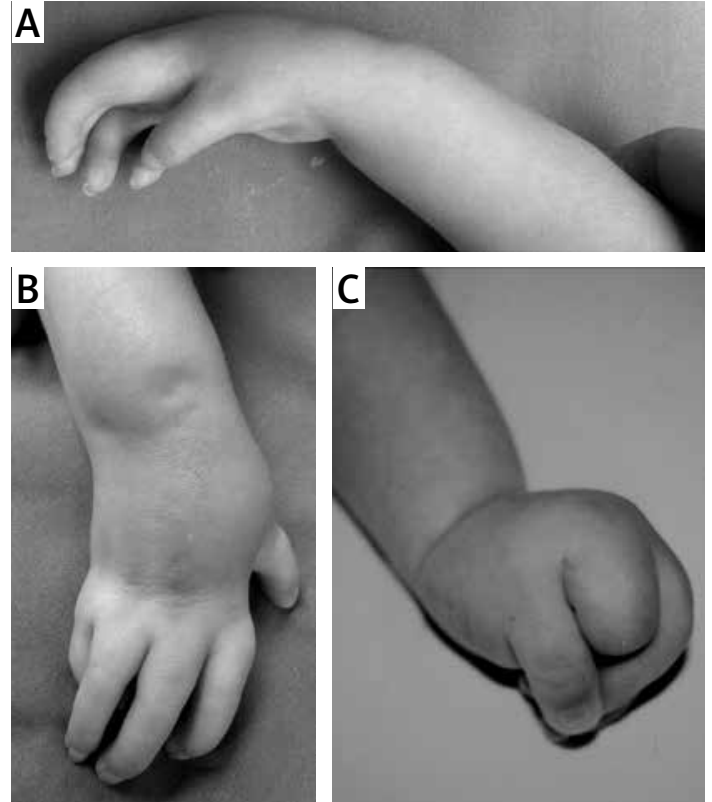

Figure 3. Clinical examples of hand contractures in arthrogryposis

- Facial skeleton - hypoplasia of the mandible (micrognathia) is often observed; in severe AMC cases, it may be accompanied by contracture and limited function of temporo-mandibular joints [74].

- Extraskeletal clinical signs and symptoms - normal intelligence; hemangioma on the forehead. Approximately $10 \%$ of patients present with abdominal wall abnormalities in the form of inguinal hernia or gastroschisis [1, 8, 62]. Varying abnormalities of the reproductive system are observed in $55 \%$ to $70 \%$ of patients [2].

\section{Distal arthrogryposis}

This is a group of genetic disorders; they differ from the sporadic classic arthrogryposis in that their inheritance is autosomal dominant. They are characterized by contractures limited mainly to the distal portions of the limbs, i.e. to wrists,

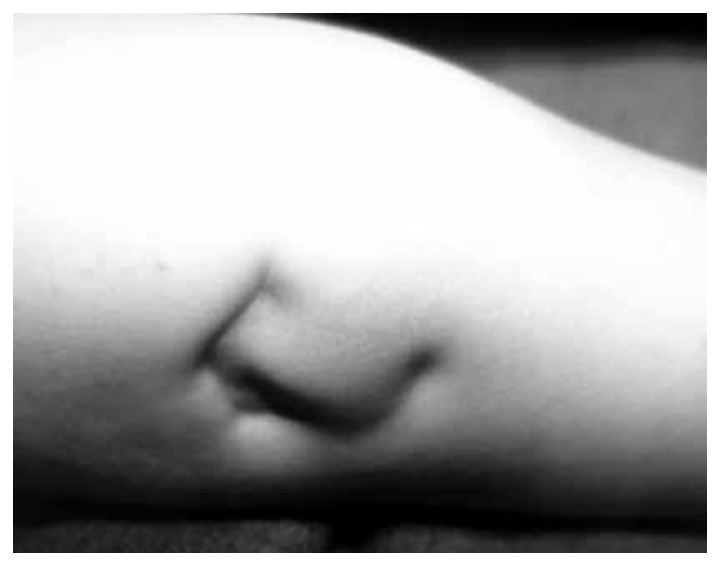

Figure 5. Skin 'dimple' overlying the knee joint 


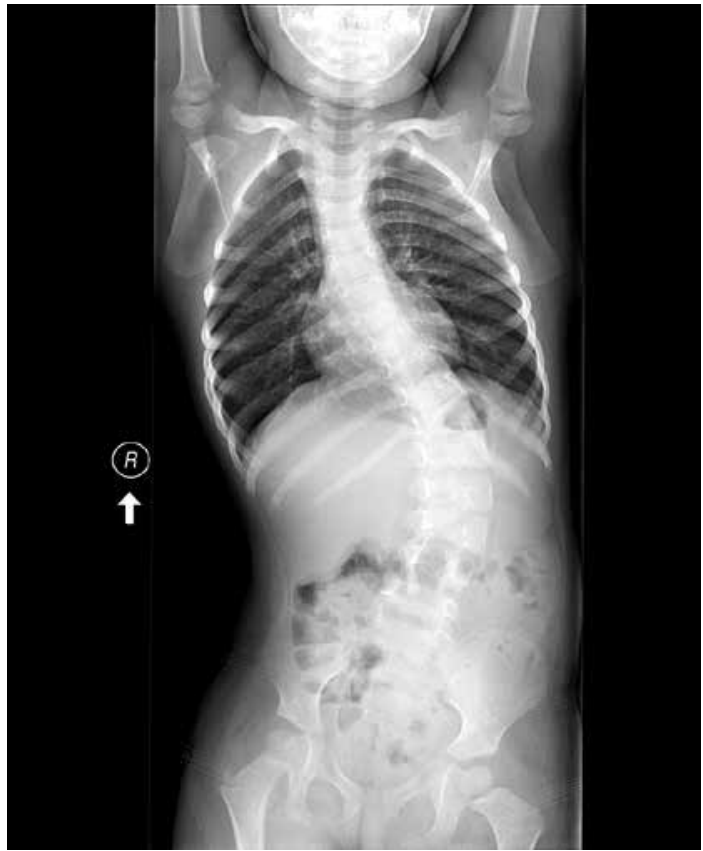

Figure 6. Antero-posterior standing spine radiograph demonstrating early onset scoliosis with significant thoracic and lumbar curve in 8 year old child with $A M C$

hands, ankles, and joints of the foot. Contractures of other joints are low-degree or are absent altogether [17, 21]. According to Bamshad et al., ten types of distal arthrogryposis had been described by $2009[17,75]$.

The diagnosis of distal arthrogryposis requires that two out of the described diagnostic criteria for upper and lower extremities are met. In the upper limb, these are: camptodactyly or pseudocamptodactyly (limitation of passive PIP extension with concomitant hyperextension of the wrist); hypoplastic or absent flexion creases on the fingers, and ulnar deviation of the wrist. The criteria for the lower limb are: talipes equinovarus; congenital flat foot (congenital vertical talus), pes calcaneovalgus, and metatarsus adductus. In familial multiple congenital contractures, the presence of only one of the above criteria is sufficient for the diagnosis of distal arthrogryposis.

A classification and main characteristics of individual types of DA are presented in Table I.

\section{Other arthrogryposes}

\section{Pterygium syndromes}

These are a separate class of genetically mediated congenital contractures, characterized by the presence of pterygia: these are skin webs located in the area of a joint and causing limitation of its range of motion. Skin webs may also be found in lateral portions of the neck, and be accompanied by cleft palate or lip, syndactyly or atypical finger-

Table I. A classification system and clinical features of distal arthrogryposes

\begin{tabular}{|c|c|}
\hline Type & Description \\
\hline I & $\begin{array}{l}\text { Characteristic clinical features are camptodactyly and talipes equinovarus with possible concomitant } \\
\text { shoulder and hip contractures. The DA1 variant is determined by a gene located on chromosome } 9[1,76]\end{array}$ \\
\hline II & $\begin{array}{l}\text { The phenotype was first described in } 1938 \text { as the Freeman-Sheldon syndrome [77], where contractures } \\
\text { of fingers and toes are accompanied by kyphosis, scoliosis, and malformations of the facial skeleton with } \\
\text { characteristic facial appearance: narrow mouth, wide cheeks, an H-shaped chin dimple, small wide-based } \\
\text { nose, high palate, and small tongue. Growth retardation, inguinal hernia, and cryptorchidism have also } \\
\text { been reported [1]. Another name of this syndrome is "whistling face" syndrome. The Freeman-Sheldon } \\
\text { syndrome is currently classified as DA2A, as a separate DA2B subtype, known as Sheldon-Hall syndrome } \\
\text { has been described; this syndrome combines clinical features of DA1 (hand and foot contractures) and some } \\
\text { features of DA2 (prominent nasolabial folds, slanted down-facing eyes, and narrow mouth) and is currently } \\
\text { considered to be probably the most common type of distal arthrogryposis }[21,78]\end{array}$ \\
\hline III & Also known as Gordon's syndrome, this rare syndrome is characterized by low stature and palatoschisis \\
\hline IV & Rare. Contractures with severe scoliosis \\
\hline V & $\begin{array}{l}\text { Contractures with ocular signs and symptoms such as limited eye motion, ptosis, strabismus, and the } \\
\text { absence of typical hand flexion creases }[21,79,80] \text {. Chest wall muscle abnormalities have also been observed, } \\
\text { potentially causing restricted respiratory movements and, consequently, pulmonary hypertension [81] }\end{array}$ \\
\hline VI & Similar to DA3, DA4; very rare, characterized by sensorineural auditory abnormalities \\
\hline VII & $\begin{array}{l}\text { Difficulties in mouth opening (trismus) and pseudocamptodactyly: wrists position in palmar flexion with } \\
\text { MCP joints in extension. Sometimes accompanied by low stature and knee flexion contractures }[1,21]\end{array}$ \\
\hline VIII & Autosomal dominant multiple pterygium syndrome \\
\hline IX & $\begin{array}{l}\text { Beals syndrome, i.e. congenital arachnodactyly with contractures of small joints of the fingers. Patients with } \\
\text { this type of arthrogryposis are tall and slender, phenotypically resembling Marfan syndrome but without } \\
\text { cardiovascular abnormalities }[82,83]\end{array}$ \\
\hline$X$ & Congenital plantar flexion contractures of the foot \\
\hline
\end{tabular}


prints. Many variations have been described with varying inheritance patterns of clinical features including autosomal dominant or recessive, e.g. lethal Bartsocas-Papas syndrome [84].

\section{Escobar's syndrome (multiple pterygium syndrome)}

Neck webs are evident at birth but are not always severe. Clinically the Escobar syndrome is characterized by facial dysmorphism, neck (bucco-sternal) webs, and hand contractures. With age, the neck webs may increase in size; the neck mobility is limited due to concomitant congenital vertebral malformations. The lumbar lordosis increases with age as well; in adolescence, lumbar lordosis and popliteal and cubital webs increase in size. The inheritance pattern is autosomal recessive, sometimes autosomal dominant; the syndrome may be associated with mental retardation. The lethal multiple pterygium syndrome is autosomal recessive; features include severe contractures, hypertelorism, cervical pterygia, narrow chest, and hypoplastic lungs.

\section{Multiple pterygium syndrome with malignant hyperthermia}

The autosomal recessive multiple pterygium syndrome is characterized by palatoschisis, scoliosis, and malignant hyperthermia during general anesthesia. Sometimes the pterygium syndrome is limited to e.g. elbows (the autosomal dominant antecubital pterygium syndrome).

\section{Larsen syndrome}

A genetically mediated, autosomal dominant syndrome with an incidence of $1 / 100,000$ live births, caused by a mutation of the gene encoding filamin B (FLNB), a component of the actin complex in the cell protein cytoskeleton. The clinical features of Larsen syndrome may include multiple contractures, most commonly in the form of talipes equinovarus. The dominant features are hypermobility and congenital dislocations of multiple joints: hips, knees, and elbows. Cervical spine instability and kyphosis may be present, leading to potentially life-threatening cervical cord injuries; other features include: laryngomalacia and/or subglottic stenosis, low body stature, hypertelorism, central facial hypoplasia, and accessory metacarpal and metatarsal bones. Mental development is usually normal [85-89].

\section{Bruck syndrome}

Extremely rare, autosomal recessive form of arthrogryposis, with combined clinical features of osteogenesis imperfecta and congenital contractures; this disease was historically described by Alfred Bruck in 1897; a modern description has been presented by Viljoen et al. [90].

\section{Treatment: general rules}

The principal treatment goal in arthrogryposis is optimization of quality of life: this includes communication capabilities, unassisted activities of daily living, social participation capacity, independent ambulation, and consequently independent living $[67,68]$. In order to achieve these goals, management must be initiated as early as possible, and optimally in the neonate and infant; this should be directed at improvement of motion in any affected joints, improvement of active motion by strengthening any functional muscles, as the limb function in arthrogryposis depends on the capability to move the limb actively, and finally correction of fixed deformities that affect activities of daily living [91]. This comprehensive approach is based on a triad of treatment tools: firstly, rehabilitation including physiotherapy, manipulation of contractures, and later social and occupational rehabilitation; secondly, individually tailored orthotic management, whether for maintenance or correction of joint mobility, and for prevention of recurrent deformities (Figure 7); thirdly, a broad spectrum of surgical techniques for correction of musculoskeletal deformities, typically found in congenital contractures $[5,6,8$, 92-94]. In a study on the quality of life in adults with arthrogryposis, Fassier et al. stressed upper limb function as the most important determinant of independent living; this especially applies to gripping, reaching to the head and face (feeding, hair care, etc), reaching the perineal area for hygiene, and dressing [6]. However, the parents of a child with arthrogryposis often place the greatest importance on independent ambulation and concentrate their attention on this ability in the treatment program [95]. It is therefore extremely important that the treatment plan and its objectives - both immediate and long-term - be communicated to both the patient and the parents; such education should be then repeated and reinforced at every consecutive treatment stage. The importance of the parents' (caregivers') role must be stressed; they should receive education about the rehabilitation protocol and should daily engage in exercises with their child [96]. Owing to the above reasons, the treatment program of the arthrogrypotic child should be individually tailored for each patient as holistic and realistic, and optimally should involve a therapeutic team including a pediatrician, an orthopedic surgeon specializing in surgical corrections in upper and lower limbs as well as spine, a geneticist, a physiotherapist, 

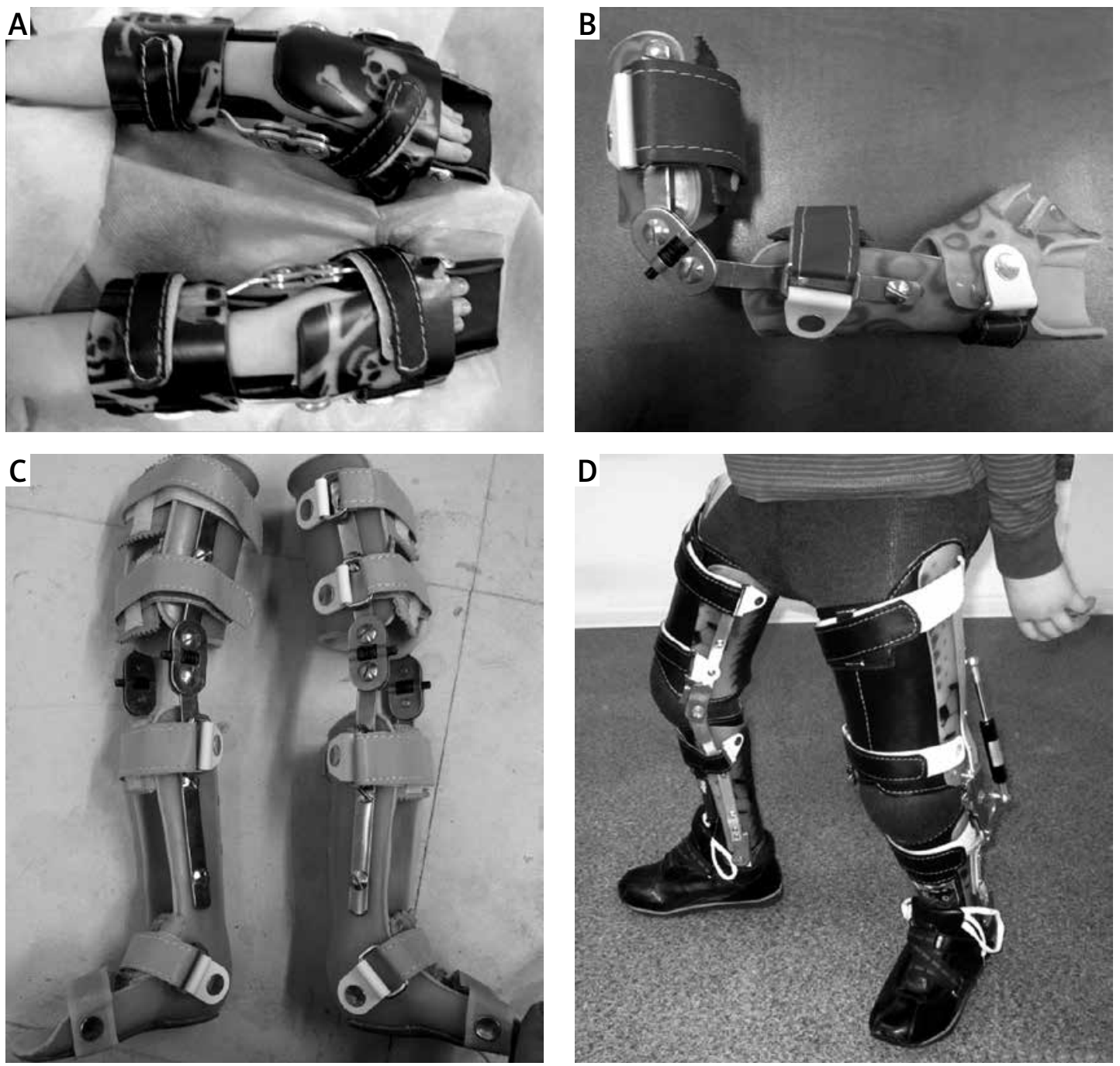

Figure 7. Examples of orthotic management for upper and lower extremities' deformations in children with AMC: A - wrist-hand orthosis (WHO) correcting palmar flexion contracture; B - elbow and wrist orthosis increasing elbow flexion; C - knee-ankle-foot orthosis (KAFO); D - KAFO used for walking improving knee active extension

an orthotic technician, and a psychologist; the team should have expertise in the treatment of patients of different age groups and with different degrees of disease severity; the team also must have the appropriate diagnostic and therapeutic armamentarium at their disposal $[5,8]$.

\section{Surgical management of upper limb contractures}

The upper limb should be considered a functional unit. The ultimate goal of treatment is restoration of personal care of the patient and the use of communication devices (e.g. telephone, computer, pen) or assistive devices used for ambulation (crutches, walker, wheelchair, car) [68]. Similarly as in the lower limbs, initiation of conservative treatment of upper limb contractures in the neonatal and early childhood period is of paramount importance.
The shoulder joint rarely requires surgical treatment; a subcapital derotation osteotomy of the humerus can be beneficial, usually in severe internal rotation contractures [97].

The correction of passive range of motion in the elbow involves exercises, manipulations and surgical procedures: in extension contractures, posterior capsule and ligament releases of the elbow joint with triceps $\mathrm{V}-\mathrm{Y}$ plasty are indicated (Figure 8) $[98,99]$. In the absence of active elbow flexion, with maintained passive motion, restoration of active flexion may be considered by means of muscle transfers, thus replacing the action of a less functional muscle with a more useful one most commonly, the triceps tendon (as a whole or the long head only) is transferred onto the biceps tendon or its remnant; other options include the latissimus dorsi, pectoralis major, and sternocleidomastoid transfers $[100,101]$. There are reports of successful pedicled gracilis transfer in 2 arthro- 
gryposis patients [102]. All these methods are burdened with complication risks, e.g. development of elbow flexion contracture, and their indications should be carefully considered as treatment failure may result in general functional deterioration, especially if the patient uses the upper limbs for independent ambulation, e.g. with crutches or a wheelchair $[6,95]$. Severe palmar flexion wrist contractures require surgical soft tissue releases on the palmar side or wedge bone resections in the distal radius or wrist arthrodesis. In flexion contractures not amenable to passive correction, an option is transferring the flexor to extensor tendons [103]. Indications for these procedures should also be carefully considered as some patients retain satisfactory function despite the presence of flexion wrist contractures [100]. In selected cases, thumb correction procedures (adduction contractures) or deepening of the first interdigital space may be indicated [95].

\section{Surgical management of the spine}

Spinal deformities develop in 30-62\% of arthrogryposis patients; therefore careful monitoring of the spine should be undertaken from the beginning of treatment [104-106]. In moderate deformities, rehabilitation measures are used; the use of corrective braces usually has limited efficacy in arthrogryposis children, but some authors recommend it in curvatures of up to $30^{\circ}$ of Cobb's angle [6, 95, 105, 106]. Early onset of deformity, pelvic obliquity, lumbar hyperlordosis and paralytic type of the curve are predictors of rapid progression and constitute indications for surgical corrections $[95,105,106]$. Satisfactory surgical correction in $A M C$ children is more difficult than in idiopathic scoliosis, and is burdened with a higher rate of complications such as pseudarthrosis or progression of angular deformity with posterior spinal instrumentation in place (the crankshaft phenomenon) $[6,95,104]$.

\section{Surgical management of the lower limb}

In AMC children, lower limb contractures are frequently multifocal and severe. They usually require constant rehabilitation and orthotic management as well as multiple surgical procedures involving the hips, knees and feet to restore mobility and functional ambulation.

\section{The hip}

Contractures of the hip are present in nearly $90 \%$ of AMC children; these are usually flexion contractures $[6,107]$. In the case of moderate contracture severity (up to $30^{\circ}$ ) the treatment may be limited to manipulations of contracted hip flexors and orthotic management [3]. Flexion contrac-
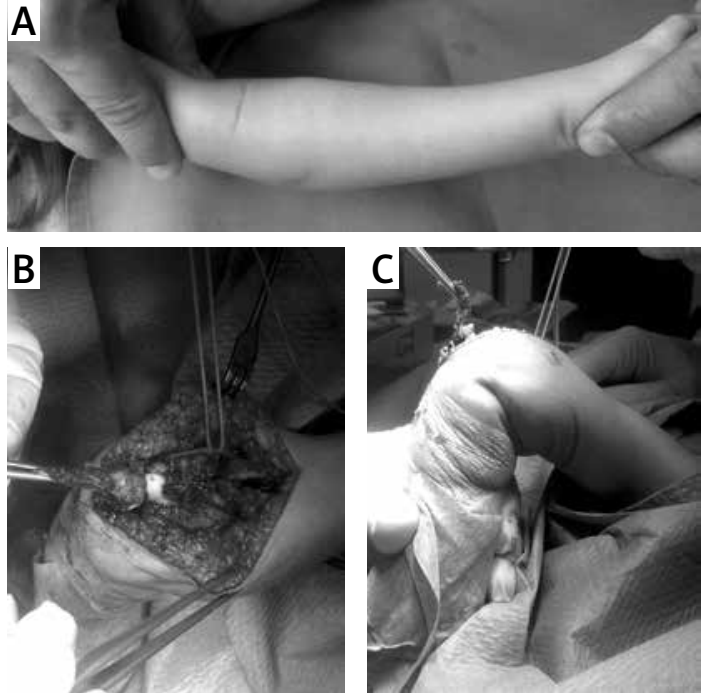

Figure 8. Clinical example presenting preoperative arthrogrypotic extension contracture of the elbow (A), intraoperative posterior capsulotomy, VY lengthening of the triceps brachii (B) and extent of surgically achieved passive elbow flexion (C)

tures over $30-45^{\circ}$ usually require surgical correction as they impair mobilization and ambulation and result in increased compensatory hyperlordosis of the lumbar spine [70]. Surgical management involves releases (transection) of contracted soft tissues (including the rectus femoris and sartorius muscles, the iliopsoas muscle, and the hip joint capsule), or, in the older child, proximal femoral extension osteotomy [108]. Moderate abduction and external rotation hip contractures usually do not require surgical treatment as they actually improve stability during ambulation, whereas severe cases may require in corrective osteotomies [93]. Hip dislocations are observed in $30 \%$ to $43 \%$ of AMC patients [95, 109, 110]. In these so-called teratogenic dislocations, the use of abduction orthotic devices, traction and closed reduction are unsuccessful and carry a risk of aseptic necrosis and/or femoral head deformation [3, 95, 109111]. Unilateral hip dislocation in an AMC child is an indication for open reduction at 6-12 months of life, supplemented in the older child by proximal femoral directional osteotomy and acetabular reconstruction [3, 112]. The treatment of bilateral hip dislocations in arthrogryposis is a subject of controversy: the proponents of leaving both hips dislocated stress that the patients continue to have satisfactory ambulation and a painless range of motion despite the dislocation, whereas the potential surgical complications, especially stiffness or limited hip motion, aseptic necrosis of the femoral head, or recurrent dislocations, can significantly reduce the patient's quality of life [3]. However, currently many authors definitely claim that in AMC patients with potential prognosis for independent ambulation, surgical correction of 
bilateral hip dislocation can result in improved functional mobility; therefore despite the usually post-surgical reduced range of hip motion, only selected patients with arthrogryposis and bilateral hip dislocation should be managed without open reduction [109, 111-114].

\section{The knee}

Knee contractures are observed in up to $85 \%$ of AMC patients and include flexion and extension contractures, whereas the former are more frequent and carry a worse prognosis for independent ambulation $[115,116]$. Flexion knee contractures of up to $20^{\circ}$ carry no significant impact on the ambulation capacity [70]. The treatment of more severe knee contractures, as an element of comprehensive treatment of the AMC patient, should be carried out simultaneously with treatment of other joints of the lower limb. In the neonate and infant, conservative treatment involves manipulations of the contracted joints with subsequent casting; this approach is more effective in correction of extension contractures [115-117]. Most flexion contractures require surgical correction and often multiple procedures. In the growth period, the most effective corrective method is knee flexor tenotomy with posterior capsulotomy and posterior cruciate ligament transection [115, 116]. The classic method of correction of flexion contractures is supracondylar extension osteotomy; however, this procedure, when carried out in the active growth period, often results in recurrence of flexion contracture, at a mean rate of one degree per month [118]. Alternative methods of correction of knee contractures include temporary anterior epiphysiodesis of the distal femoral growth cartilage $[119,120]$ or the use of circular external fixators with gradual soft tissue correction - the llizarov method [121, 122]. Van Bosse et al. advocate combining posterior soft tissue releases of the knee (usually carried out with two separate incisions - lateral and medial) with gradual contracture correction on the llizarov apparatus, applied in one surgical session [122].

Manually non-correctible extension contractures are an indication for surgical management in the form of selective rectus snip (e.g. percutaneous) with subsequent manipulation and casting [123, 124]. In older children, extension contracture can be an indication for extensor apparatus $\mathrm{V}$ - $\mathrm{Y}$ plasty with anterolateral and anteromedial capsulotomy. Another option is shortening femoral shaft osteotomy resulting in relative elongation of the knee extensor apparatus [123-125].

Postoperative use of orthotic devices is beneficial by assisting mobilization and ambulation; moreover - thanks to the helicoid hinge knee brace - they allow gradual improvement of the correction obtained during surgery.

\section{The foot}

Pes equinovarus is the most common deformity of the musculoskeletal system in the patient with multiple congenital contractures: it is observed in approximately $70 \%$ of symptomatic arthrogryposis patients and in $98-100 \%$ of AMC patients [126-129]. Approximately $2-12 \%$ of patients present with the so-called congenital flatfoot (congenital vertical talus) [130]. Isolated equinus deformity, congenital metatarsus adductus, pes equinovalgus, or pes calcaneovalgus deformities are occasionally seen (approx. $1 \%$ of patients) [126-129].

The objective of treatment of the feet in arthrogryposis is conversion of the deformed foot into a painless "platform", capable of supporting the body weight on the whole foot surface area (referred to as "plantigrade foot"), allowing mobilization and independent ambulation; the foot shape should accommodate both orthotic devices and standard footwear [131]. Similarly as in the case of other contractures, the treatment of foot deformities should be started as early as possible in the form of manual manipulations with subsequent casting. Traditionally this treatment is aimed at preparation of the skin and neurovascular structures of the foot for the eventual surgical correction [92, 129, 132]. It should be stressed that conservative treatment of arthrogrypotic foot deformities is more difficult and requires longer time than in phenotypically identical idiopathic deformities; if not performed gently it can result, due to non-compliance of tissues, in iatrogenic fractures [126, 133]. Classically, after reaching the maximum conservative correction (plateau), surgical interventions were undertaken; these include capsuloligamentotomy of the ankle, subtalar, and talonavicular joints, usually combined with resection (not lengthening) of the contracted tendons: the Achilles, the flexor hallucis longus, and flexor digitorum longus; peroneal tendons; occasionally the flexor digitorum brevis, and the plantar aponeurosis [134, 135].

In some severe or neglected cases of foot deformities, notably in older children, surgical excision of the talus (talectomy, astragalectomy) is undertaken; this procedure corrects the foot deformity by relative "lengthening" of soft tissues and formation of a tibiocalcaneal joint, usually with a small range of motion - but capable of supporting the foot for weight bearing [135-140].

There are recent reports on successful use of the Ponseti method in the management of equinovarus deformity in arthrogryposis [132, 141-144]. 
Independent from the primary correction method (soft tissue release vs. primary astragalectomy) the recurrence rate of foot deformities after primary surgical treatment of the equinovarus foot in arthrogryposis may approach $75-100 \%$ and patients usually require 3-4 revision procedures per foot $[126,129]$. The revision procedures vary and depend on the type of deformity and patient age; options include repeat soft tissue releases, astragalectomy, naviculectomy (total resection of the navicular bone), combined bone/joint resection procedures; corrections using ring external fixation devices such as the Ilizarov or Taylor Spatial Frame, and supramalleolar osteotomies [126-129, 138, 145-151].

\section{Conflict of interest}

The authors declare no conflict of interest.

\section{References}

1. Hall JG. Arthrogryposis multiplex congenita: etiology, genetics, classification, diagnostic approach and general aspects. J Pediatr Orthop B 1997; 6: 159-66.

2. Sells JM, Jaffe KM, Hall JG. Amyoplasia, the most common type of arthrogryposis: the potential for good outcome. Pediatrics 1996; 97: 225-31.

3. Stilli S, Antonioli D, Lampasi M, Donzelli O. Management of hip contractures and dislocations in arthrogryposis. Musculosceletal Surg 2012; 96: 17-21.

4. Lampasi M, Antonioli D, Donzelli O. Management of knee deformities in children with arthrogryposis. Musculosceletal Surg 2012; 96: 161-9.

5. Thompson GH, Bilenker RM. Comprehensive management of arthrogryposis multiplex congenita. Clin Orthop Relat Res 1985; 194: 6-14.

6. Fassier A, Wicart P, Dubosset J, Seringe R. Arthrogryposis multiplex congenita. Long term follow up study from birth until skeletal maturity. J Child Orthop 2009; 3: 383-90.

7. Sarwark JF, MacEwen GD, Scott CI Jr. Amyoplasia (a common form of arthrogryposis). J Bone Joint Surg Am 1990; 72: 465-9.

8. Sarwark JF, MacEwen GD, Scott CL. A multidisciplinary approach to amyoplasia congenita ("classic arthrogryposis"). Orthop Trans 1986; 10: 130.

9. Obeidat MM, Audat Z, Khriesat W. Short-term functional outcome in children with arthrogryposis multiplex congenita after multiple surgeries at an early age. J Multidiscip Health 2012; 5: 195-200.

10. Otto AW. Monstrum humanum extremitatibus incurvatus: monstrorum sexcentorum descripto anatomica in Vratislaviae Museum. Clin Orthop 1985; 194: 4.

11. Schantz A. Ein fall von multiplen kongenitalen kontrakturen. Z Orthop Chir 1898; 5: 9.

12. Rosenkranz E. Ueber kongenitale kontrakturen der oberen extremitaten. Z Orthop Chir 1905; 14: 52.

13. Stern WG. Arthrogryposis multiplex congenita. JAMA 1923; 81: 1507.

14. Scheldon W. Amyoplasia congenita (Multiple congenital articular rigidity: arthrogryposis multiplex congenita). Arch Dis Child 1932; 7: 117-36.
15. Rink BD. Arthrogryposis: a review and approach to prenatal diagnosis. Obstet Gynecol Survey 2011; 66: 369-77.

16. Kalampokas E, Kalampokas T, Sofoudis C, Deligeoroglou E, Botsis E. Diagnosing arthrogryposis multiplex congenita: a review. ISRN Obstet Gynecol 2012; 2012: 264918.

17. Hall JG, Reed SD, Greene G. The distal arthrogryposes: delineation of new entities - review and nosologic discussion. Am J Med Genet 1982; 11: 185-239.

18. Fahy MJ, Hall JG. A retrospective study of pregnancy complications among 828 cases of arthrogryposis. Genet Couns 1990; 1: 3-11.

19. Darin N, Kimber E, Kroksmark AK, Tulinius M. Multiple congenital contractures: birth prevalence, etiology, and outcome. J Pediatr 2002; 140: 61-7.

20. Hall JG, Reed SD, Driscoll EP. Part I. Amyoplasia. A common, sporadic condition with congenital contractures. Am J Med Genet 1983; 15: 571-90.

21. Bamshad M, Van Heest AE, Pleasure D. Arthrogryposis: a review and update. J Bone Joint Surg Am 2009; 91 Suppl. 4: 40-6.

22. Witters I, Moerman P, Fryns JP. Fetal akinesia deformation sequence: a study of 30 consecutive in utero diagnoses. Am J Med Genet 2002; 113: 23-8.

23. Mossinger AC. Fetal akinesia deformation sequence: an animal model. Pediatrics 1983; 72: 857-63.

24. Swinyard CA, Bleck EE. The etiology of arthrogryposis. Clin Orthop 1985; 194: 15-29.

25. Drachman DB, Coulombre A. Experimental clubfoot and arthrogryposis multiplex congenita. Lancet 1962; 2: 523-6.

26. Robertson GG, Wiliamson AP, Blattner RJ. A study of abnormalities in early chick embryos inoculated with New Castle disease virus. J Exp Zool 1955; 129: 5-43.

27. Pena SDJ, Shokeir MHK. Syndrome of camptodactyly, multiple ankyloses, facial anomalies and pulmonary hypoplasia: a lethal condition. J Pediatr 1974; 85: 373-5.

28. Brodtkorb E, Torbergsen T, Nakken KO, Andersen K, Gimse R, Sjaastad O. Epileptic seizures, arthrogryposis, and migrational brain disorders: a syndrome? Acta Neurol Scand 1994; 90: 232-40.

29. Vuopala K, Leisti J, Herva R. Lethal arthrogryposis in Finland - a clinico-pathological study of 83 cases during thirteen years. Neuropediatrics 1994; 25: 308-15.

30. Fedrizzi E, Botteon G, Inverno M, Ciceri E, D'Incerti L, Dworzak F. Neurogenic arthrogryposis multiplex congenita: clinical and MRI findings. Pediatr Neurol 1993; 9: 343-8.

31. Moerman P, Barth PG. Olivo-ponto-cerebellar atrophy with muscular atrophy, joint contractures and pulmonary hypoplasia of prenatal onset. Virchows Archiv 1987; 410: 339-45.

32. Bingham PM, Shen N, Rennert H, et al. Arthrogryposis due to infantile neuronal degeneration associated with deletion of the SMN(T) gene. Neurology 1997; 49: 848-51.

33. Burglen L, Amiel J, Viollet L, et al. Survival motor neuron gene deletion in the arthrogryposis multiplex congenita - spinal muscular atrophy association. J Clin Invest 1996; 98: 1130-2.

34. Banker BQ. Arthrogryposis multiplex congenita; spectrum of pathologic changes. Hum Pathol 1986; 17: 656-72.

35. Bankier BQ. Neuropathologic aspects of arthrogryposis multiplex congenita. Clin Orthop Relat Res 1985; 194: 30-43. 
36. Boylan KB, Ferriero DM, Greco CM, Sheldon RA, Dew M. Congenital hypomyelination neuropathy with arthrogryposis multiplex congenita. Ann Neurol 1992; 31: 337-40.

37. Charnas L, Trapp B, Griffin J. Congenital absence of peripheral myelin: abnormal Schwann cell development causes lethal arthrogryposis multiplex congenita. Neurology 1988; 38: 966-74.

38. Hoffmann K, Muller JS, Stricker S, et al. Escobar syndrome is a prenatal myasthenia caused by disruption of the acetylcholine receptor fetal g subunit. Am J Hum Genet 2006; 79: 303-12.

39. Morgan NVD, Brueton LA, Cox P, et al. Mutations in the ebryolan subunit of the acetylcholine receptors (CHRNG) case lethal and Escobar variants of multiple pterygium syndrome. Am J Med Genet 2006; 79: 390-5.

40. Sombekke BHF, Molenaar WM, Van Essen AJ, Schoots CJF. Lethal congenital muscular dystrophy with arthrogryposis multiplex congenita: three new cases and review of the literature. Pediatr Pathol 1994; 14: 277-85.

41. Seidahmed MZ, Sunada Y, Ozo CO, et al. Lethal congenital muscular dystrophy in two sibs with arthrogryposis multiplex: new entity or variant of cobblestone lissencephaly syndrome? Neuropediatrics 1996; 27: 305-10.

42. Kimber E, Tajsharghi H, Kroksmark AK, Oldfors A, Tulinius MA. Mutation in the fast skeletal muscle troponin I gene causes myopathy and distal arthrogryposis. Neurology 2006; 67: 597-601.

43. North KN, Beggs AH. Deficiency of a skeletal muscle isoform of alpha-actinin (alpha-actinin-3) in merosin-positive congenital muscular dystrophy. Neuromuscular Disorders 1996; B: 305-10.

44. McPherson E, Zabel C. Mitochondrial mutation in a child with distal arthrogryposis. Am J Med Genet 2006; 140: 184-5.

45. Laubscher B, Janzer RC, Krahenbuhl S, Hirt L, Deonna T. Ragged-red fibers and complex I deficiency in a neonate with arthrogryposis congenita. Pediatr Neurol 1997; 17: 249-51.

46. Robaszkiewicz K, Moraczewska J. Wrodzone miopatie choroby mięśni szkieletowych związane z zaburzeniami struktury i funkcji filamentu aktynowego. Postep Hig Med Dosw 2011; 14: 347-56.

47. Romero NB, Monnier N, Viollet L, et al. Dominant and recessive central core disease associated with RYR1 mutations and fetal akinesia. Brain 2003; 126: 2341-9.

48. Muntoni F, Brockington M, Godfrey A, et al. Muscular dystrophies due to defective glycosylation of dystroglycan. Acta Myol 2007; 26: 129-35.

49. Quijano-Roy S, Mbieleu B, Bonnemann CG, et al. De novo LMNA mutations cause a new form of congenital muscular dystrophy. Ann Neurol 2008; 64: 177-86.

50. Hastabacka J, de la Chapelle A, Mahtani MM, et al. The diastrophic dysplasia gene encodes a novel sulphate transporter: positional cloning by fine - structure linkage disequilibrum mapping. Cell 1994; 78: 1073-87.

51. Bonilla-Musoles F, Machado LE, Osborne NG. Multiple congenital contractures (congenital multiple arthrogryposis). J Perinatal Med 2002; 30: 99-104.

52. Parashar SY, Anderson PJ, McLean N, Djohansjah M, David DJ. Spectrum of features in pterygium syndrome. Asian J Surg 2006; 29: 104-8.

53. Gillerot Y, Koulischer L. Restrictive dermopathy. Am J Med Genet 1987; 27: 239-40.

54. Riemersma S, Vincent A, Beeson D, et al. Association of arthrogryposis multiple congenita with maternal an- tibodies inhibiting fetal acetylocholine receptor function. J Clin Invest 1996; 98: 2358.

55. Dalton P, Clover L, Wallerstein R, et al. Fetal arthrogryposis and maternal serum antibodies. Neuromusc Disord 2006; 16: 481-91.

56. Vincent A, Jacobson L, Plested P, et al. Antibodies affecting ion channel function in acquired neuromyotonia, in seropositive and seronegative myasthenia gravis, and in antibody-mediated arthrogryposis multiplex congenita. Ann N Y Acad Sci 1998; 841: 482-96.

57. Livingstone IR, Sack GJ. Arthrogryposis multiplex congenita occurring with multiple sclerosis. Arch Neurol 1984; 41: 1216-7.

58. Moutard-Codou ML, Dellur MM, Dulac O, et al. Severe neonatal myasthenia with arthrogryposis. Presse Med 1987; 16: 615-8.

59. Jago RH. Arthrogryposis following treatment of maternal tetanus with muscle relaxants. Arch Dis Child 1970; 45: 277-9.

60. Hammond E, Donnenfeld AE. Fetal akinesia. Obstet Gynecol Surv 1995; 50: 240-9.

61. Coelho CE, Sarmento MF, Veiga CM, et al. Misoprostol embryotoxicity: clinical evaluation of fifteen patients with arthrogryposis. Am J Med Genet 2000; 95: 297-301.

62. Hall JG, Reed SD, McGilivray BC, et al. Part II: Amyoplasia: twinning in amyoplasia - a specific type of arthrogryposis with an apparent excess of discordantly identical twins. Am J Med Genet 1983; 15: 591-9.

63. Hall JG. Arthrogryposis associated with unsuccessful attempts at termination of pregnancy. Am J Med Genet 1996; 63: 293-300.

64. Reed SD, Hall JG, Riccardi VM, et al. Chromosomal abnormalities associated with congenital contractures (arthrogryposis). Clin Genet 1985; 27: 353-72.

65. Pena SD, Shokier MH. Syndrome of camptodactyly, multiple ankyloses, facial anomalies and pulmonary hypoplasia - further delineation and evidence for autosomal recessive inheritance. Birth Defects Orig Artic Ser 1976; 12: 201-8.

66. Narkis G, Landau D, Manor E, et al. Genetics of arthrogryposis: linkage analysis approach. Clin Orthop 2005; 456: 30-5.

67. Thompson GH, Bilenker RM. Comprehensive management of arthrogryposis multiplex congenita. Clin Orthop Relat Res 1985; 194: 6-14.

68. Bevan WP, Hall JG, Bamshad M, Staheli LT, Jaffe KM, Song K. Arthrogryposis multiplex congenita (amyoplasia): an orthopaedic perspective. J Pediatr Orthop 2007; 27: 594-600.

69. Silberstein EP, Kakulas BA. Arthrogryposis multiplex congenita in Western Australia. J Paediatr Child Health 1998; 34: 518-23.

70. Hoffer M, Swank S, Eastman F, Clark D, Teitge R. Ambulation in severe arthrogryposis. J Pediatr Orthop 1983; 3: 293-7.

71. Shah A, Kumar SJ. Complications on management of arthrogryposis multiplex congenita. In: Complications on pediatric orthopedic surgery. Epps C Jr, Bowen R (eds.). Lippincott Company, Philadelphia 1995.

72. Greggi T, Martikos K, Pipitone E, et al. Survival treatment of scoliosis in a rare disease: arthrogryposis. Scoliosis 2010; 5: 24-34.

73. Yingsakmongkol W, Kumar SJ. Scoliosis in arthrogryposis multiplex congenita: results after nonsurgical and surgical treatment. J Pediatr Orthop 2000; 20: 656-61.

74. Steinberg B, Nelson VS, Feinberg SE, Calhoun C. Incidence of maxillofacial involvement on arthrogryposis 
multiplex congenita. J Oral Maxillofac Surg 1996; 54: 956-9.

75. Bamshad M, Jorde LB, Carey JC. A revised and extended classification of the distal arthrogryposes. Am J Med Genet 1996; 65: 277-81.

76. Bamshad M, Watkins WS, Zenger RK, et al. A gene for distal arthrogryposis type I maps to the pericentromeric region of chromosome 9. Am J Hum Genet 1994; 55: 1153-8.

77. Freeman EA, Sheldon J. Cranio-carpotarsal dystrophy: undescribed congenital malformation. Arch Dis Child 1938; 13: 227-83.

78. Krakowiak PA, Bohnsack JF, Carey JC, Bamshad M. Clinical analysis of a variant of Freeman-Sheldon syndrome (DA2B). Am J Med Genet 1998; 76: 93-8.

79. Palotta R, Ehresmann T, Fusilli P. Ocular findings in distal arthrogryposis. Ophtalmic Genet 2001; 22: 125-30.

80. Schrander-Stuper CTRM, Howeler CJ, Reekers ABA, et al. Arthrogryposis, ophtalmoplegia, and retinopathy: confirmation of a new type of arthrogryposis. J Med Genet 1992; 30: 78-80.

81. Williams MS, Elliot CG, Bamshad MJ. Pulmonary disease is a component of distal arthrogryposis type 5 . Am J Med Genet 2007; 143: 752-6.

82. Romas Arroyo MA, Weaver DD, Beals RK. Congenital contractural arachnodactyly: report of four additional families and review of literature. Clin Genet 1985; 27: 570-81.

83. Viljoen D, Ramesar R, Behari D. Beals syndrome: clinical and molecular investigations in a kindred of Indian descent. Clin Genet 1991; 39: 181-8.

84. Hall JG, Reed SD, Rosenbaum KN, et al. Limb pterygium syndrome: a review and report of eleven patients. Am J Med Genet 1982; 12: 377-409.

85. Larsen LJ, Schottstaedt ER, Bost FC. Multiple congenital dislocations associated with characteristic facial abnormality. J Pediatr 1950; 37: 574-81.

86. Bicknell LS, Farrington-Rock C, Shafeghati Y, et al. A molecular and clinical study of Larsen syndrome cause by mutations in FLNB. J Med Genet 2007; 44: 89-98.

87. Kaissi AA, Altenhuber J, Grill F, Klaushofer K. Significant traumatic atrophy of the spinal cord in connection with severe cervical vertebral body hypoplasia in a boy with Larsen syndrome: a case report and review of the literature. Cases J 2009; 2: 6729.

88. Karakas K, Percin EF, Percin S. Surgical risk factors in Larsen's syndrome. Acta Orthop Belg 2000; 66: 495-8.

89. Hoeve JH, Joosten MFK, Bogers JJCA, et al. Malformation and stenosis of the cricoid cartilage in association with Larsen's syndrome. Laryngoscope 1997; 107: 792-4.

90. Viljoen D, Versfeld G, Beighton P. Osteogenesis imperfecta with congenital joint contractures (Bruck syndrome). Clin Genet 1989; 36: 122-6.

91. Kroksmarck AK, Kimber E, Jerre R, et al. Muscle involvement and motor function in amyoplasia. Am J Med Gen A 2006; 140: 1757-67.

92. Napiontek M. Leczenie zniekształceń narządu ruchu w arthrogryposis multiplex congenita. Materiały Naukowe XXVII Zjazdu PTOiTr, Szczecin 1990; 221-5.

93. Kandzierski G, Gregosiewicz A, Gil L, Drabik Z. Leczenie bezoperacyjne i operacyjne kończyn dolnych u dzieci z wrodzoną sztywnością stawów. Materiały Naukowe XXVII Zjazdu PTOiTr, Szczecin 1990; 219-20.

94. Kowalski M, Lewandowska H, Skórzak B. Wyniki leczenia operacyjnego $\mathrm{w}$ artrogrypozie. Materiały Naukowe XXVII Zjazdu PTOiTr, Szczecin 1990; 237-40.
95. Bernstein R. Arthrogryposis and amyoplasia. J Am Acad Orthop Surg 2002; 10: 417-24.

96. Skórzak B, Kalniet-Szurek A, Lewandowska H, Kowalski M. Możliwości i granice usprawnienia dzieci z artrogrypoza. Materiały Naukowe XXVII Zjazdu PTOiTr, Szczecin 1990; 248-51.

97. Zlotow DA, Kozin SH. Posterior elbow release and humeral osteotomy for patients with arthrogryposis. J Hand Surg Am 2012; 37: 1078-82.

98. Axt MW, Niethard FU, Doderlein L, Weber M. Principles of treatment of the upper extremity im arthrogryposis multiplex congenita. J Pediatr Orthop B 1997; 6: 179-85.

99. Van Heest A, James MA, Lewica A, Anderson KA. Posterior elbow capsulotomy with triceps lengthening for treatment of elbow extension contracture in children with arthrogryposis. J Hand Surg Am 1998; 23: 1063-70.

100. Chomiak J, Dungl P. Restoration of elbow flexion using pectoral muscle transfer in patients with arthrogryposis multiplex congenita. Part I: surgical method, rehabilitation and clinical results. Acta Chir Orthop Czech 2002; 69: 333-43.

101. Puchala J, Sulko J, Radło W. Leczenie operacyjne kończyn górnych w arthrogryposis multiplex congenita. Chir Narz Ruchu Ortop Pol 2001; 66: 143-9.

102. Doi K, Arakawa Y, Hattori Y, Baliarsing AS. Restoration of elbow flexion with functioning free muscle transfer in arthrogryposis: a report of two cases. J Bone J Surg Am 2011; 93: 105.

103. Mennen U. Early corrective surgery of the wrist and elbow in arthrogryposis multiplex congenita. J Hand Surg Br 1993; 18: 304-7

104. Greggi T, Martikos K, Pipitone E, et al. Survival treatment of scoliosis in a rare disease: arthrogryposis. Scoliosis 2010; 5: 24

105. Yingsakmongkol W, Kumar SJ. Scoliosis in arthrogryposis multiplex congenita: results after nonsurgical and surgical treatment. J Pediatr Orthop 2000; 20: 656-61.

106. Herron LD, Westin GW, Dawson EG. Scoliosis in arthrogryposis multiplex congenita. J Bone Joint Surg Am 1978; 60: 293-9.

107. Sarwak JF, MacEwen GD, Scott CI Jr. Amyoplasia (a common form of arthrogryposis). J Bone Joint Surg Am 1990; 72: 465-9.

108. Feluś J, Radło W, Miklaszewski K, Sulko J. Leczenie przykurczy stawu biodrowego osteotomią międzykrętarzową kości udowej u dzieci z artrogrypozą. Chir Narz Ruchu Ortop Pol 2007; 72: 15-7.

109. Akazawa H, Oda K, Mitani S, Yoshitaka T, Asaumi K, Inoue $\mathrm{H}$. Surgical management of hip dislocation in children with arthrogryposis multiplex congenita. J Bone Joint Surg Br 1998; 80: 636-40.

110. Södergard J. Hip in arthrogryposis multiplex congenita. Rev Chir Orthop Reparatrice Appar Mot 1996; 82: 403-9.

111. Le Bel ME, Gallien R. The surgical treatment of teratologic dislocation of the hip. J Pediatr Orthop B 2005; 14: 331-6.

112. Yau PW, Chow W, Li YH, Leong JC. Twenty-year follow up of hip problems in arthrogryposis multiplex congenita. J Pediatr Orthop 2002; 22: 359-63.

113. Wada A, Yamaguchi T, Nakamura T, et al. Surgical treatment of hip dislocation in amyoplasia-type arthrogryposis. J Pediatr Orthop B 2012; 21: 381-5.

114. Szöke G, Staheli LT, Jaffe K, Hall JG. Medial-approach open reduction of hip dislocation in amyoplasia-type arthrogryposis. J Pediatr Orthop 1996; 16: 127-30. 
115. Murray C, Fixsen JA. Management of knee deformity in classical arthrogryposis multiplex congenita (amyo plasia congenita). J Pediatr Orthop B 1997; 6: 186-91.

116. Thomas B, Schopler S, Wood W, Oppenheim WL. The knee in arthrogryposis. Clin Orthop Relat Res 1985; 194: 87-92.

117. Södergard J, Ryöppy S. The knee in arthrogryposis multiplex congenita. J Pediatr Orthop 1990; 10: 177-82.

118. DelBello DA, Watts HG. Distal femoral extension osteotomy for knee flexion contracture in patients with arthrogryposis. J Pediatr Orthop 1996; 16: 122-6.

119. Palocaren T, Thabet AM, Rogers K, et al. Anterior distal femoral stapling for correcting knee flexion contracture in children with arthrogryposis: preliminary results. J Pediatr Orthop 2010; 30: 169-73.

120. Al-Aubaidi Z, Lundgard B, Pedersen NW. Anterior distal femoral hemiepiphysodesis in the treatment in fixed flexion knee contracture in neuromuscular patients. J Child Orthop 2012; 6: 313-8.

121. Brunner R, Hefti F, Tgetgel JD. Arthrogrypotic joint contracture at the knee and the foot: correction with a circular frame. J Pediatr Orthop B 1997; 6: 192-7.

122. van Bosse HJ, Feldman DS, Anavian J, Sala DA. Treatment of knee flexion contractures in patients with arthrogryposis. J Pediatr Orthop 2007; 27: 930-7.

123. Lampasi M, Antonioli D, Donzelli O. Management of knee deformities in children with arthrogryposis. Mus culoskelet Surg 2012; 96: 161-9.

124. Fucs PM, Svartman C, de Assumpção RM, Lima Verde SR. Quadriceps plasty in arthrogryposis (amyoplasia): long-term follow-up. J Pediatr Orthop B 2005; 14: 219-24.

125. Roy DR, Crawford AH. Percutaneous quadriceps recession: a technique for management of congenital hyperextension deformiities of the knee in the neonate. J Pediatr Orthop 1989; 9: 717-9.

126. Drummond DS, Cruess RL. The management of the foot and ankle in arthrogryposis multiplex congenita. J Bone Joint Surg 1978; 86: 22-7.

127. Guidera KJ, Drennan JC. Foot and ankle deformities in arthrogryposis multiplex congenita. Clin Orthop Relat Res 1985; 194: 93-8.

128. Sodergard J, Ryoppy S. Foot deformities in arthrogryposis multiplex congenita. J Pediatr Orthop 1994; 14 768-72.

129. Niki H, Staheli LT, Mosca VS. Management of clubfoot deformity in amyoplasia. J Pediatr Orthop 1997; 17: 803807.

130. Aroojis AJ, King MM, Donohoe M, Riddle EC, Kumar SJ. Congenital vertical talus in arthrogryposis and other contractural syndromes. Clin Orthop Relat Res 2005; 434: 26-32.

131. Lloyd-Roberts GC, Lettin AW. Arthrogryposis multiplex congenita. J Bone Joint Surg Br 1970; 52: 494-508.

132. Kowalczyk B, Lejman T. Short-term experience with Ponseti casting and the Achilles tenotomy method for clubfeet treatment in arthrogryposis multiplex congenita. J Child Orthop 2008; 2: 365-71.

133. Gravev AM, Boal DK, Wallach DM, Segal LS. Metaphyseal fractures mimicking abuse during treatment for clubfoot. Pediatr Radiol 2001; 31: 559-63.

134. Widemann RF, Do TT, Burke SW. Radical soft-tissue release of the arthrogrypotic clubfoot. J Pediatr Orthop 2005; 14: 111-5.

135. Green ADL, Fixen JA, Lloyd-Roberts GC. Talectomy for arthrogryposis multiplex congenita. J Bone Joint Surg 1984; 66-B: 697-9.
136. D’Souza H, Aroojis A, Chawara GS. Talectomy in arthrogryposis: analysis of results. J Pediatr Orthop 1998; 18 760-4.

137. Segal LS, Mann DC, Feiwell E, Hoffer MM. Equinovarus deformity in arthrogryposis and myelomeningocoele: evaluation of primary talectomy. Foot Ankle 1989; 10: 12-6.

138. Hsu LCS, Jaffray D, Leong JCY. Talectomy for clubfoot in arthrogryposis. J Bone J Surg 1984; 66-B: 694-6.

139. Dias LS, Stern LS. Talectomy in the treatment of resistant talipes equinovarus deformity in myelomeningocoele and arthrogryposis. J Pediatr Orthop 1987; 7: 39-41.

140. Cassis N, Capdevilla R. Talectomy for clubfoot in arthrogryposis. J Pediatr Orthop 2000; 20: 652-5.

141. Boehm S, Limpaphayom N, Alaee F, Sinclair MF, Dobbs MB. Early results of the Ponseti method for treatment of clubfoot in distal arthrogryposis. J Bone Joint Surg Am 2008; 90: 1501-7.

142. Morcuende JA, Dobbs MB, Frick SL. Results of the Ponseti method in patients with clubfoot associated with arthrogryposis. lowa Orthop J 2008; 28: 22-6.

143. Van Bosse HJP, Marangoz S, Lehman W, Sala DA. Correction of arthrogrypotic clubfoot with a modyfied Ponseti technique. Clin Prothop Relat Res 2009; 467: 1283-93.

144. Janicki JA, Narayanan UG, Harvey B, Roy A, Ramseier LE, Wright JG. Treatment of neuromuscular and syndrome-associated (non-idiopathic) clubfeet using the Ponseti method. J Pediatr Orthop 2009; 29: 393-7.

145. Mubarak SJ, Van Valin SE. Osteotomies of the foot for cavus deformities in children. J Pediatr Orthop 2009; 29: 294-9.

146. Mubarak SJ, Dimeglio A. Navicular excision and cuboid closing wedge for severe cavovarus foot deformities: a salvage procedure. J Pediatr Orthop 2011; 31: 551-6.

147. Nicomedez FP, Li YH, Leong JC. Tibiocalcaneal fusion after talectomy in arthrogrypotic patients. J Pediatr Orthop 2003; 23: 654-7.

148. Eidelman M, Katzman A. Treatment of arthrogrypotic foot deformities with the Taylor Spatial Frame. J Pediatr Orthop 2011; 31: 429-34.

149. Lejman T, Sułko J, Kowalczyk B. Treatment for recurrence clubfoot with the Ilizarov technique. Chir Narz Ruchu Ortop Pol 1998; 63: 39-45.

150. Choi IH, Yang MS, Chung CY, Cho TJ, Sohn YJ. The treatment of recurrent arthrogrypotic club foot in children by the Ilizarov method. A preliminary raport. J Bone Joint Surg Br 2001; 83: 731-7.

151. Nelmann K, Weiner DS, Morscher MA, Jones KC. Multiplanar supramalleolar osteotomy in the management of complex rigid deformities in children. J Child Orthop 2009; 3: 39-46. 